\title{
Strategic Implications of Water Usage: an Analysis in Brazilian Mining Industries
}

\author{
Roberto Schoproni Bichueti', Clandia Maffini Gomes², Isak Kruglianskas ${ }^{3}$, Jordana Marques Kneipp 4 , \\ Luciana Aparecida Barbieri da Rosa ${ }^{5}$
}

\begin{abstract}
This study aims at identifying the practices of water use management and the business performance in industries in the Brazilian mineral sector. To this end, a descriptive and quantitative study was developed, using the survey method, in industries associated with the Brazilian Mining Institute - IBRAM. The water use management practices were identified based in a model addressing the following aspects: water accounting, risk assessment, direct operations, supply chain, and stakeholders engagement. The business performance was measured from a model involving the following dimensions: economic, environmental and social. Among the results, the risks assessment involved and the direct operations practices stand out, in order to reduce the amount of water used and waste discharges. The need for greater engagement of industries with the stakeholders and the supply chain, through a more integrated and collaborative management, was also evident.
\end{abstract}

Keywords: sustainability; water; management; mining.

\footnotetext{
1,2,4,5 Federal University of Santa Maria (UFSM).Av. Roraima, 1000-74C-4210. Santa Maria-RS, Brazil. Email:'robertobichueti@gmail.com ${ }^{3}$ Sao Paulo University (USP). Luciano Gualberto, 908. Sao Paulo-SP, Brazil. 05508. E-mail: ikruglia@gmail.com.
} 


\section{Introduction}

Understanding corporate sustainability, combining economic prosperity, social responsibility and environmental aspects, represents a challenge for managers. It is imperative to understand that companies are not isolated, but are part of a reality that requires the management of scarce resources and concern for social issues (Barbieri, 2007; Savitz and Weber, 2006).

In addition to this concern, the pressure on organizations regarding this theme is growing, not only in terms of legislation. To the extent that society is increasingly aware of the environmental aspects and thus comes to assess corporate behavior, adapting to these issues becomes critical in terms of strategy and competitiveness. According to Lacy et. al. (2010), we are entering a new era in which sustainability will be a key point for business success, being built on strategic and operational issues.

In the context of the mineral industry, which develops an essentially extractive activity, through the use of natural resources and an intense relationship with the environment, sustainable development becomes an even greater challenge. Despite the importance of mining in the economic context, discussions about the extraction of nonrenewable resources, changes in the environmental landscape and in the working conditions of workers are some of the issues discussed (Azapagic, 2004; Mclellan et al., 2009).

According to a study from the National Water Agency ANA and the Brazilian Mining Institute - IBRAM (ANA and IBRAM, 2006), it can be stated that the mineral industry is among the heaviest users of water in Brazil and has the most peculiarities. Its activities range from complex projects with large environmental impacts and, often, with modern and efficient managements of such impacts, to small miners, with poor environmental control and planning.

It is known that the water-mining interaction is not limited to the exploration phase of the mine, but permeates all ore beneficiation processes, and hydrological impacts may extend long after the end of activities (ANA and IBRAM, 2006). According to Gunson et al. (20I2), in addition to the amount of water used in their production process, certain procedures, such as leakage of tailings and waste dumping in waterways can cause contamination of surface and ground water. Furthermore, power consumption is also high in mining, in view of activities such as pumping, treatment and heating and cooling systems. Thus, the efficient use of water can reduce the amount used in the process, its impacts and energy consumption, being considered a strategic resource for a more sustainable mineral industry.
Inserted in this context, this study aims to identify the practices of water use management and business performance in economic, social and environmental terms for industries in the Brazilian mineral sector.To this end, this paper discusses initially the management of water use, the prospects of sustainable development in the mineral sector and sustainable performance indicators. Subsequently, it describes the research method adopted in the development of the study and, finally, shows its results and conclusions.

\section{Water use management and mining}

Because it is a vital resource for humanity, it is essential to discuss the relationship between water and sustainability. One of the most important assets, if not the primary, to life on Earth is on the agenda. According to Tundisi (2008), the availability of good quality fresh water is directly linked with economic development, quality of life and the maintenance of the planet's cycles. Although classified as a renewable resource, water shows signs of deterioration in almost all parts of the planet, with alarming predictions regarding its quality and quantity, and common sense says that it will be the scarcest resource of the 2 I st century (Barbieri, 2007).

Used in various activities, water is essential for economic development. Among the most frequent uses, according to Tundisi (2008), it is possible to highlight domestic use, irrigation, industrial use and hydroelectricity. According to the Brazilian Company for Agricultural and Environmental Research - EMBRAPA (2009), the production of food, specifically the agricultural sector, is responsible on average for $65 \%$ of fresh water consumption in the country. The industrial sector, likewise, requires large amounts of water in the production process of many products essential to society. One can illustrate this use, according to Miranda (2004), with the following: producing I ton of steel consumes 280ton of water; the manufacture of $1 \mathrm{~kg}$ of paper may require $700 \mathrm{~kg}$ of water; I $\mathrm{kg}$ of textile product requires 150 liters $(L)$ of water; and fabrication of an automobile requires 50 times its weight in water, among others.

The concerns about the water issue are not limited to its availability. Water quality should also be evaluated.According to EMBRAPA (2009), in urban areas, in general, problems with water supply are directly related to demand growth, waste and uncontrolled urbanization. Moreover, sanitation contributes to the problem, since $90 \%$ of domestic sewage and $70 \%$ of industrial effluents are thrown untreated into rivers, ponds and coastal waters, which has generated a high level of pollution (EMBRAPA, 2009).

Water management has been discussed since the Stockholm Conference in 1972, being considered by researchers as the natural resource that has aroused the most concern among 
researchers. Agenda 2I, a product of the Conference on Environment and Development held in 1992 in Rio de Janeiro, highlights the importance of maintaining the supply of good quality water for the population of the entire planet, in addition to preserving the hydrological, biological and chemical properties of ecosystems, with the necessary adaptation of human activities within the limits of nature's capacity (ANA and IBRAM, 2006).

The water resources management in Brazil is founded on Law No. 9433, January 1997, which established the National Policy of Water Resources (PNRH). According to Article I of this law, water is considered a public good, a limited natural resource with economic value, but does not regulate collection instruments. Furthermore, it promotes the activity of river basin committees, the participation of government, and the community of users in a decentralized manner, and the creation of the National Water Resources Management (SINGREH). Noteworthy are also the instruments for water resources management, stipulated in article 5. They are: Plans for Water Resources, the classification of bodies of water into classes, the granting of rights of use, charging for use, compensation to municipalities and the Information System on Water Resources (Brazil, 1997).

Given the importance and necessity of water in the corporate environment, particularly in the industrial level, water use management is not only a public issue, but should be understood also as a concern for corporate management. According to Lambooy (20II), there are several drivers that justify and lead companies to develop sustainable policies for managing water use. We highlight, first, self-interest, because there are costs for using this feature, generating benefits for the company. Moreover, many activities directly depend on its availability, that is, scarcity compromises the production. A third driver is the company's reputation in a society increasingly aware of the environmental impacts, affecting, for example, its corporate image. The fourth driver is the risk associated with community pressures facing local authorities and the last factor refers to the high investment needed for water management (Lambooy, 20I I). Corroborating, Ceres (2010) states that companies should worry about their "Iicense to operate", especially in areas of water stress caused by scarcity of such resource.

Accordingly, Lambooy (20II) presents several tools, guidelines and initiatives developed worldwide, involving the reduction of water use in the corporate environment and its sustainable management. Among these actions, we highlight the CEO Water Mandate (CEO Water Mandate, UNEP and GC, 20I0), the water footprint (Gerbens-Leenes and Hoekstra, 2008), the global water tool (WBCSD, 2007) and the GEMI Water Sustainability Planner/Tool (GEMI, 2002).
Despite various initiatives and actions currently exist in relation to water management at the corporate level, Lambooy (20I I) highlights the results indicated by research conducted by Ceres (2010), whose aim was to understand how companies present in critical and vulnerable sectors regarding the use of water are evaluating, managing and disclosing their risks in relation to its operations, its supply chain and its products. The corporate speeches were evaluated by a framework developed by Ceres (20I0), covering the following dimensions: (1) Water accounting, (2) Risks Assessment, (3) Direct Operations, (4) Supply Chain and (5) Stakeholders engagement.Among the main findings of the study by Ceres (20I0), the low performance relative to corporate speeches about the risks associated with water use and performance of enterprises is emphasized. However, it is noteworthy that, among the sectors studied, the one who had the best performance was the mineral sector (Ceres, 2010).

In addition to the results presented in said study, there are some initiatives that signal a closer relationship between the mineral sector and the sustainable management of water use. Among these, we highlight the performance of the Brazilian Mining Institute (IBRAM) and the National Water Agency (ANA), which at the national level, are working to raise awareness of the industry in search of efficient water use in mining activities (ANA and IBRAM, 2006).

Those involved in mining agree on the duality that appears when talking about the water-mine relationship. If, on one hand, it is absolutely needed in various activities and processes in this industry, on the other hand it is the source of many problems and entails additional costs. These problems occur because the mining occurs in groundwater level, beyond the direct interference of surface waters, imposing the need for drainage areas of mines, producing hydrological, environmental and economic effects, which require the proper management of these waters (ANA and IBRAM, 2006).

In this sense, we highlight the importance of controlling water quality in mining, with the effective management of this resource through active and passive prevention, treatment and correction methods. Thus, the success and viability of the mining activity strongly depend on its interaction with water, requiring knowledge of the hydrological context and appropriate interaction, in phases of exploration, operation, closure and post-closure of the mines, as well as in the treatment of ores (ANA and IBRAM, 2006).

According to Barbieri et. al. (20I0), the movement for corporate sustainability followed a faster path compared to the movement for quality. While the latter appeared in the postwar era, and had its highest development only in the 80s, sustainability had its starting point in 1987, with the publication of the Brundtland Report (WCED, 1987), and in less 
than 20 years, was already present in many business sectors, at least in ideology. However, unlike quality, adherence of companies to sustainable development was initially 'from the outside-in' through the pressure of various audiences. Only in recent years, being part of this movement came to be induced for reasons of business nature, in that it has become a competitive factor (Barbieri, 2007; Barbieri et. al. 20I0).

Inserted in this context is the mineral industry. We know the importance of mineral goods for modern life, as they have a socially wide and necessary function, with products that make the basis for various industries and represent an important role in the national economy (DNPM, 2009). The ores are present in various products such as ceramics, construction, pharmaceuticals, electronics, cosmetics, glass, metals, paints, among others. However, in view of the nature of the activities of the mineral industry, sustainable development represents a major challenge for the sector, in economic, social and environmental terms (Azapagic, 2004).

According to McLellan et al. (2009), progress has been made in the search for alignment in the mineral industry and commitment to sustainable development, by reducing the impact caused by the production process.Azapagic (2004) corroborates the claim that this industry has been engaged in the debate of sustainability, developing strategies to meet the challenge of sustainable development. An example initiative is Minnig's project, Minerals and Sustainable Development (MMSD) called Global Mining Initiative (GMI, 20I2), which aims to promote the concept of sustainable development in the mineral sector.

According to Hilson and Murck (2000), integration requires a commitment to continuous environmental and socioeconomic improvement, from mineral exploration to operation to the end of the chain. In this sense, the authors state that it is necessary to: improve planning, enhance environmental management, implement cleaner technology, generating greater engagement with stakeholders, build partnerships and invest in training (Hilson and Murck, 2000). McLellan et al. (2009) corroborate the importance of planning for the implementation of sustainable development in mining. For the authors, the greatest opportunity for reducing the impacts caused is in the design phase of the project, and not in the control of the operation or in the post-operational phase.

Taking into account the social and environmental economic issues, Azapagic (2004) presents the main impacts of the mineral industry, as described in Figure I.

Thus, the importance of sustainable development in the organizational environment can be seen, and, in particular, the challenge posed to the mineral industry. In this sense, we see the importance of sustainable performance indicators, described in the next chapter.

\section{Sustainable performance indicators}

The need to create sustainable development indicators is explicit in Agenda 2I, a product of the United Nations International Conference on Environment and Development. Moreover, this conference created the Comission of Sustainable Development - CSD in order to monitor the progress in the path of sustainable future through the creation of appropriate tools for this assessment (Bellen, 2006).

According to Bellen (2006), one of the main difficulties found in building indicators in this theme is the scope of the central concept of sustainable development. Thus, it is possible to find systems of indicators that operate in different dimensions: environmental, economic and social.Aiming to identify

\begin{tabular}{l|l|l}
\hline \multicolumn{1}{c|}{ Economic Issues } & \multicolumn{1}{c}{ Environmental Issues } & \multicolumn{1}{c}{ Social Issues } \\
\hline - Contribution to GDP and wealth & - Loss of biodiversity & - Bribery and corruption \\
generation & - Emissions in the air & - Employment Generation \\
- Costs, sales and profits & - Energy use & - Education of employees and skill \\
- Distribution of income and & - Global warming and other & - Equal opportunities and non- \\
wealth & environmental impacts & - discrimination \\
- Investments (Capital, employees, & - Land use, management and & - Health and safety \\
communities, pollution prevention & rehabilitation & - Human rights and business ethics \\
and mine closure) & - Derangement & - Labor/management relationship \\
- Value for shareholders & - Product toxicity & - Relationship with local \\
- Added value & - Use of resources and availability & communities \\
& - Solid waste & - Involvement with stakeholders \\
& - Use of water, wastewater, & - Distribution of wealth \\
\hline
\end{tabular}

Figure I - The main sustainability issues in the mineral sector. Source:Azapagic (2004, p. 644)

ISSN: 07I 8-2724. (http://www.jotmi.org)

Journal of Technology Management \& Innovation (c) Universidad Alberto Hurtado, Facultad de Economía y Negocios. 
the main tools used in the evaluation of sustainability, the author conducted a comparative analysis among the most internationally recognized methodologies. According to the author, we can highlight the most memorable projects: Ecological footprint method (EFM), Dashboard of sustainability (DS) and Barometer of sustainability (BS).

Among the projects mentioned by Bellen (2006) is the Global Reporting Initiative (GRI), which deserves attention due to its wide distribution in the organizational environment. This is an initiative that aims to develop and globally disseminate guidelines for the preparation of sustainability reports, organized in the following categories: economic, environmental and social (GRI, 2006). Despite the GRI (2006) being designed for use by organizations of any size, sector and location, sector supplements were developed, ie, versions of the GRI guidelines adapted to some sectors of the economy, assisting in the preparation of reports addressing Specific impacts in an internationally comparable manner.Among them, we note the sector supplement regarding mining and metals, whose aim is to describe the guidelines focused specifically on these sectors (GRI, 20I0).

According to Azapagic (2004), the model developed by the GRI $(2006,2010)$ has been established as one of the most important communication patterns and has been used by several companies in the mineral sector. Moreover, the author argues that new models for assessing sustainability in the mineral sector are being developed, although these initiatives are in the early stages and require more efforts.

\section{Method}

Aiming to identify the practices of water use management and business performance in economic, social and environmental terms, for industries in the Brazilian mineral sector, we developed a descriptive and quantitative research. According to Hair et. al (2003), descriptive research plans are specifically structured to measure the characteristics described in a particular research question. A research of the quantitative type, according to Malhotra and Birks (2006), is one that seeks to quantify the data and usually applies some form of statistical analysis.

We used the survey research method, which according to Hair et. al. (2003), is a procedure for collection of primary data from individuals.

\section{Conceptual Model}

The conceptual model of this research, built in order to reach the research objectives and concepts present in the theoretical framework, identify de Management of water use and de business performance.
The variables related to water use management practices were developed based on the model proposed by Ceres (20I0). In this model, the following business practices are evaluated: (I) Water accounting, (2) Risks Assessment, (3) Direct Operations, (4) Supply Chain and (5) Stakeholders engagement.

The variables related to business performance are based on the model developed by the Global Reporting Initiative GRI (2006) and its supplement regarding the mineral sector (GRI, 20I0). The business performance is evaluated through the following dimensions: (I) economic, (2) environmental and (3) social.

Finally, the control variables consisting of: (I) time of operation, (2) firm size, and (3) the mineral product produced. Regarding the size of the company, we used two classifications: (I) according to the number of employees, proposed by the Brazilian Service of Support for Micro and Small Enterprises - SEBRAE (2004) and (2) according to gross operating revenue, in 2010 , with the classification proposed by the National Bank for Economic and Social Development BNDES (20II).

\section{Sampling and procedures for data collection and analysis}

The survey was targeted to mineral industries associated with the Brazilian Mining Institute - IBRAM, considering that this is the largest organization representing the Brazilian mineral industry. As a selection criterion, we adopted the participation of the industry in IBRAM, and companies associated with other associations linked to this institute. Were excluded from this list the purely commercial businesses and/or service providers, being restricted only to those with the industrial activity of mining. Thus, the research universe included 270 companies.

The questionnaires were sent to companies via email and phone calls were made, so that they were aware of the importance and reliability of the research. This procedure was essential for the increased rate of return. The collection period was comprised between October $20 \mathrm{II}$ and April $20 \mathrm{I} 2$. At the end of the data collection, we obtained a rate of return of $13.3 \%$, totaling 36 questionnaires. Thus, because it is a non-representative sample of this population, the results cannot be generalized for all industries of the Brazilian mineral sector, being restricted to companies participating in this survey.

The data analysis was done by statistical analysis, using univariate techniques (descriptive statistics), with the support of Microsoft Excel and SPSS v. 17. 


\section{Result analysis}

From the data obtained, it is possible to present search results. Initially, we describe the characteristics of industrial enterprises belonging to the sample, to then present the results relating to water use management and business performance in these industries.

\section{Sample profile}

In this section, are presented the characterization of the companies participating in the research, in order to know the profile of these industries in terms of performance and size. Regarding the length of existence of the companies, it was found that, on average, they have 38 years of existence. The youngest company of this sample has three years of experience in the market and the oldest has been in business for 130 years.

In order to identify the size of the companies, two classifications were used.The first classification presents data regarding the number of employees, according to the classification proposed by SEBRAE (2004), described in Table I.

According to this classification, it is observed that the sample is distributed mainly among small, medium and large businesses. For the most part, companies are considered medium-sized enterprises (100-499 employees).
The second classification on the size of the companies, according to BNDES (20I I), takes into account the gross operating revenues, measured in 2010. Table 2 below shows the profile according to this criterion. It can be noticed that, according to this classification, most of the sample is considered small.

Finally, companies were classified according to the mineral product extracted by them. As shown in Table 3, most of the companies engaged in the extraction of mineral aggregates (22.2\%). The industries of limestone, coal and iron are also remarkable.

From the characterization of the companies studied, it is possible to present the results obtained in relation to water use management and business performance in economic, social and environmental terms, which is the goal of this study.

\section{Strategic water use management}

The evaluation of water use management, based on the model proposed by Ceres (2010), was made from five dimensions, according to the following business practices: control of the amount of water; assessment of the risks involved; operational practices; supply chain; and engagement with stakeholders. Table 4, shows the results obtained in relation to practices adopted in the mining industries studied.

\begin{tabular}{|l|c|c|}
\hline \multicolumn{1}{|c|}{ Company Size - Number of Employees } & Frequency & (\%) \\
\hline Microenterprise (up to 19 employees) & 3 & 8.3 \\
\hline Small business (20-99 employees) & 10 & 27.8 \\
\hline Medium business (100-499 employees) & 12 & 33.3 \\
\hline Large Company (over 500 employees) & 11 & 30.6 \\
\hline Total & 36 & 100.0 \\
\hline
\end{tabular}

Table I - Company size - Number of employees

\begin{tabular}{|l|c|c|}
\hline \multicolumn{1}{|c|}{ Company Size - Gross operating revenue (2010) } & Frequency & (\%) \\
\hline Microenterprise (up to 2.4 million reais); & 4 & 11.1 \\
\hline Small business (from 2.4 to 16 million reais) & 11 & 30.6 \\
\hline Medium business (16 to 90 million reais) & 9 & 25.0 \\
\hline Medium-large business (90 to 300 million reais) & 3 & 8.3 \\
\hline Large company (over 300 million reais) & 8 & 22.2 \\
\hline No Response & 1 & 2.8 \\
\hline Total & 36 & 100.0 \\
\hline
\end{tabular}

Table 2 - Company size - Gross operating revenue (2010)

ISSN: 07 I8-2724. (http://www.jotmi.org)

Journal of Technology Management \& Innovation (c) Universidad Alberto Hurtado, Facultad de Economía y Negocios. 


\begin{tabular}{|l|c|c|}
\hline \multicolumn{1}{|c|}{ Mineral Product } & Frequency & (\%) \\
\hline Mineral aggregates & 8 & 22.2 \\
\hline Limestone & 7 & 19.4 \\
\hline Mineral coal & 6 & 16.7 \\
\hline Iron & 4 & 11.1 \\
\hline Carbonate & 2 & 5.6 \\
\hline Steel & 1 & 2.8 \\
\hline Aluminum & 1 & 2.8 \\
\hline Asbestos & 1 & 2.8 \\
\hline Kaolin & 1 & 2.8 \\
\hline Copper & 1 & 2.8 \\
\hline Dolomite & 1 & 2.8 \\
\hline Tin & 1 & 2.8 \\
\hline Niobium & 1 & 2.8 \\
\hline Serpentine & 1 & 2.8 \\
\hline Total & $\mathbf{3 6}$ & $\mathbf{1 0 0 . 0}$ \\
\hline
\end{tabular}

Table 3 - Mineral products extracted

\begin{tabular}{|c|c|c|c|}
\hline \multicolumn{4}{|l|}{ Water use management } \\
\hline Variables & Mean & $\begin{array}{l}\text { Standard } \\
\text { deviation }\end{array}$ & $\begin{array}{l}\text { Variation } \\
\text { coefficient }\end{array}$ \\
\hline 1 Water Accounting & 0.53 & 0.313 & 58.59 \\
\hline $\begin{array}{l}\text { 1.1 Quantitative control of the amount of water withdrawn / consumed in } \\
\text { the corporate and local level }\end{array}$ & 0.68 & 0.375 & 55.59 \\
\hline $\begin{array}{l}1.2 \text { Quantitative control of the discharge of wastewater at the corporate } \\
\text { and local level }\end{array}$ & 0.68 & 0.391 & 57.91 \\
\hline $\begin{array}{l}\text { 1.3 Quantitative control of the amount of water used in the products of } \\
\text { their suppliers (water footprint of suppliers) }\end{array}$ & 0.25 & 0.351 & 140.37 \\
\hline 2 Risk Assessment & 0.74 & 0.327 & 44.13 \\
\hline $\begin{array}{l}\text { 2.1 Knowledge of their exposure to physical risks related to water use. } \\
\text { (Eg. scarcity, drought) }\end{array}$ & 0.76 & 0.363 & 47.85 \\
\hline 2.2 Knowledge of their exposure to reputational risks related to water use. & 0.78 & 0.336 & 43.15 \\
\hline 2.3 Knowledge of their exposure to regulatory risks related to water use. & 0.73 & 0.377 & 51.96 \\
\hline 2.4 Knowledge of their exposure to litigation risks related to water use. & 0.70 & 0.376 & 53.78 \\
\hline 3 Direct Operations & 0.67 & 0.313 & 46.43 \\
\hline 3.1 Policies and management systems related to water & 0.72 & 0.377 & 52.41 \\
\hline $\begin{array}{l}3.2 \text { Information on non-compliance, violations or penalties associated } \\
\text { with water use or wastewater discharge }\end{array}$ & 0.73 & 0.389 & 53.25 \\
\hline 3.3 Effort to reduce water use at the corporate level & 0.79 & 0.308 & 39.01 \\
\hline 3.4 Effort to reduce wastewater discharge at the corporate level & 0.76 & 0.340 & 44.67 \\
\hline 3.5 Quantitative goals to reduce water use at the corporate and local level & 0.53 & 0.438 & 82.57 \\
\hline $\begin{array}{l}\text { 3.6 Quantitative goals to reduce wastewater discharge at the corporate } \\
\text { and local level }\end{array}$ & 0.51 & 0.433 & 85.22 \\
\hline 4 Supply Chain & 0.34 & 0.313 & 93.01 \\
\hline
\end{tabular}




\begin{tabular}{|l|c|c|c|}
\hline 4.1 Effort to assess, train or assist their suppliers in water management & 0.37 & 0.361 & 98.44 \\
\hline $\begin{array}{l}\text { 4.2 Effort to collect and monitor data on the impacts of their suppliers in } \\
\text { relation to water }\end{array}$ & 0.30 & 0.335 & 110.67 \\
\hline $\begin{array}{l}4.3 \text { Quantitative goals to reduce impacts related to water in the supply } \\
\text { chain }\end{array}$ & 0.34 & 0.367 & 108.43 \\
\hline $\mathbf{5}$ Stakeholders engagement & 0.47 & 0.356 & 75.64 \\
\hline $\begin{array}{l}\text { 5.1 Effective collaboration with local and national governments, commu- } \\
\text { nities and international institutions in issues related to water and sanita- } \\
\text { tion }\end{array}$ & 0.48 & 0.384 & 80.38 \\
\hline $\begin{array}{l}\text { 5.2 Effective collaboration with local and national governments, com- } \\
\text { panies, NGOs and the community in the management and restoration of } \\
\text { watersheds }\end{array}$ & 0.48 & 0.388 & 81.16 \\
\hline $\begin{array}{l}\text { 5.3 Mechanisms of consultation with local communities and NGOs on the } \\
\text { impacts in relation to water when implementing or expanding operations }\end{array}$ & 0.46 & 0.390 & 85.65 \\
\hline \multicolumn{2}{|c|}{$\mathrm{N}=36$} & \\
\hline
\end{tabular}

Table 4 -Water use management - descriptive statistics

'The averages refer to the level of agreement of the companies on the implementation of this practice in a scale ranging from 0 to I, where $I$ is the highest level of agreement.

${ }^{2}$ The averages of each dimension were calculated from the arithmetic average of its variables.

According to the data presented, one can highlight the practices concerning the assessment of the risks involved in the use of water, which had the highest means in the study and lowest coefficient of variation. This is linked to the companies' awareness of the various risks associated with water to which they are exposed.This considers physical, reputational, regulatory and litigation risks. The results presented confirm the importance of managing water use in enterprises of this sector, according to the risks they are exposed to.

The high rates, in relation to the assessment of the risks involved, corroborate the study of Ceres (2010). In this study, the companies of the mineral sector surveyed had high averages in relation to the assessment of the risks involved, especially the physical and regulatory risks. This is due, according to Ceres (2010), to the specificities of this activity, which depends on the availability of water on a large scale (associated to physical hazards), and is subject to increasing pressure from legislation (regulatory risks).

Also noteworthy are the averages obtained in the dimensions related to operational practices. This category considers the water use management at the operational level in industries and is associated with policies and systems for water management, in compliance with regulations related to water and efforts and quantitative goals for reducing water use and discharge of wastewater. In this dimension is the variable with the highest individual average, which refers to the effort to reduce water use at the corporate level. It is worth noting, also, the efforts to reduce discharges of wastewater at the corporate level.
The third dimension with higher averages in the management of water use refers to the control of quantity of water. This category considers the control, by companies, of the volume of water used, the discharge of waste water and the volume of water used by their suppliers, through quantitative data.

Finally, the two dimensions with less expressive results can be cited. Engagement with stakeholders considers the involvement of the businesses with stakeholders. It assesses the degree of participation and collaboration with governments, local and national, companies and the community for the management and restoration of watersheds, drinking water and sanitation. These results corroborate with Hilson and Murck (2000), who highlight the need for greater integration of the mineral sector and its stakeholders.

The lowest average, in relation to the management of water use, refers to the supply chain. This dimension assesses the degree of involvement of businesses with their suppliers, identifying the company's efforts to meet the data from their suppliers in relation to water use, assess their performance and support their training of regarding the use of water. The low averages in this dimension show that the integration industry/suppliers in relation to water, in the companies surveyed, is still incipient.

From this analysis, it is possible to identify the practices adopted by industries for water use management, where the evaluation and understanding of the risks involved and the practices at the operational level were highlighted, in 
order to reduce the amount of water used. The need for greater integration of industries with their stakeholders and supply chain, through an integrated and collaborative in order to improve outcomes in the management of water use, was also evidenced.

From these results, we can move towards the business performance of these industries, presented in the following section.

\section{Business Performance}

The assessment of business performance of the companies surveyed, measured according to the model based on GRI (2006, 2010), had three dimensions: economic, social and environmental. Accordingly, two analyses were performed. The first observes the impacts of the company in each of the aforementioned categories. The second identifies indicators, in terms of percentage, related to the evolution of each variable.

Initially, the results for the impact caused on business performance are presented, as shown in Table 5.

\begin{tabular}{|c|c|c|c|}
\hline \multicolumn{4}{|l|}{ Business performance - Impacts } \\
\hline Variables & Mean & $\begin{array}{l}\text { Standard } \\
\text { deviation }\end{array}$ & $\begin{array}{l}\text { Variation } \\
\text { coefficient }\end{array}$ \\
\hline 1 Economic dimension & $\mathbf{0 . 5 8}$ & 0.298 & 51.82 \\
\hline 1.1 Increased direct economic value generated and distributed & 0.66 & 0.323 & 48.82 \\
\hline $\begin{array}{l}\text { 1.2 Higher presence of policies, practices and proportion of spendings on } \\
\text { locally-based suppliers at significant operation locations. }\end{array}$ & 0.59 & 0.342 & 58.27 \\
\hline $\begin{array}{l}1.3 \text { Increased proportion of senior management hired from the local com- } \\
\text { munity at significant operation locations. }\end{array}$ & 0.51 & 0.365 & 72.17 \\
\hline $\begin{array}{l}\text { 1.4 Development and impact of infrastructure investments and services } \\
\text { provided primarily for public benefit }\end{array}$ & 0.54 & 0.376 & 69.75 \\
\hline 2 Environmental dimension & 0.63 & 0.264 & 41.72 \\
\hline 2.1 Increased use of recycled materials. & 0.61 & 0.337 & 55.15 \\
\hline 2.2 Reduction of direct and indirect energy consumption & 0.66 & 0.330 & 49.88 \\
\hline 2.3 Reduction of water consumption & 0.64 & 0.376 & 58.59 \\
\hline $\begin{array}{l}2.4 \text { Increase in the percentage of rehabilitation of land used in production } \\
\text { activities and/or extractive use }\end{array}$ & 0.68 & 0.362 & 53.25 \\
\hline 2.5 Reductions in emissions of greenhouse gases, effluents and waste & 0.64 & 0.355 & 55.88 \\
\hline $\begin{array}{l}2.6 \text { Reduction of the total amounts of overload, rocks, tailings and sludges } \\
\text { and their associated risks. }\end{array}$ & 0.66 & 0.343 & 51.70 \\
\hline 2.7 Initiatives to reduce environmental impacts of products and services & 0.76 & 0.306 & 40.41 \\
\hline $\begin{array}{l}2.8 \text { Increase in the percentage of recovered products and packaging in rela- } \\
\text { tion to total sales }\end{array}$ & 0.40 & 0.401 & 100.18 \\
\hline $\begin{array}{l}2.9 \text { Reduction of environmental impacts on the transport of goods and } \\
\text { materials used for the organization's operations, as well as the transport of } \\
\text { workers. }\end{array}$ & 0.64 & 0.356 & 56.01 \\
\hline 3 Social dimension & 0.59 & 0.206 & 34.92 \\
\hline 3.1 Reduction of employee turnover & 0.79 & 0.240 & 30.58 \\
\hline $\begin{array}{l}\text { 3.2 Reduction of rates of injury, occupational diseases, lost days, absentee- } \\
\text { ism and work-related fatalities }\end{array}$ & 0.88 & 0.195 & 22.07 \\
\hline 3.3 Development of programs on health and safety at work & 0.85 & 0.259 & 30.38 \\
\hline 3.4 Investment in employee training & 0.79 & 0.235 & 29.81 \\
\hline $\begin{array}{l}3.5 \text { Increase in the percentage of contractors and suppliers who underwent } \\
\text { screening related to human rights }\end{array}$ & 0.62 & 0.358 & 58.08 \\
\hline
\end{tabular}

ISSN: 07 I8-2724. (http://www.jotmi.org) 


\begin{tabular}{|l|l|l|c|}
\hline 3.6 Development of measures aimed at reducing discrimination cases & 0.66 & 0.372 & 56.53 \\
\hline 3.7 Measures undertaken to abolish child labor and/or slavery & 0.72 & 0.451 & 62.98 \\
\hline 3.8 Reduction of operations in or near the territories of indigenous peoples & 0.25 & 0.418 & 169.00 \\
\hline $\begin{array}{l}\text { 3.9 Implementation of programs and practices that seek to reduce the im- } \\
\text { pacts of operations on communities }\end{array}$ & 0.63 & 0.401 & 63.53 \\
\hline $\begin{array}{l}\text { 3.10 Reduction of conflicts related to land use with local communities and } \\
\text { indigenous peoples. }\end{array}$ & 0.33 & 0.417 & 125.24 \\
\hline $\begin{array}{l}\text { 3.11 Initiatives developed to promote the resettlement and rehabilitation of } \\
\text { those resettled }\end{array}$ & 0.22 & 0.357 & 162.60 \\
\hline 3.12 Increased percentage of operations with closure plans & 0.39 & 0.432 & 111.12 \\
\hline 3.13 Investment in anti-corruption mechanisms. & 0.41 & 0.450 & 108.69 \\
\hline $\begin{array}{l}\text { 3.14 Reduction of significant fines and non-monetary sanctions for non- } \\
\text { compliance with laws and regulations }\end{array}$ & 0.63 & 0.426 & 67.20 \\
\hline $\begin{array}{l}\text { 3:15 Reduction in the impacts on health and safety of clients by assessing } \\
\text { the life cycle of products and services }\end{array}$ & 0.54 & 0.423 & 77.61 \\
\hline $\begin{array}{l}\text { 3.16 Adequacy of information regarding the requirements for labeling pro- } \\
\text { cedures of products and services }\end{array}$ & 0.54 & 0.447 & 82.61 \\
\hline $\begin{array}{l}\text { 3.17 Adequacy of programs and progress related to materials management, } \\
\text { aimed at sustainability. }\end{array}$ & 0.67 & 0.346 & 51.72 \\
\hline $\begin{array}{l}\text { 3:18 Increased involvement of the parts concerned, including participation } \\
\text { in decision making on matters that concern them. }\end{array}$ & 0.69 & 0.338 & 49.05 \\
\hline \multicolumn{1}{|c|}{$\mathrm{N}=36$} & & \\
\hline
\end{tabular}

Table 5 - Business performance (impacts) - descriptive statistics

'The averages refer to the level of agreement of the companies on the implementation of this practice in a scale ranging from 0 to $I$, where $I$ is the highest level of agreement.

${ }^{2}$ The averages of each dimension were calculated from the arithmetic average of its variables.

According to the results, one can see that the greatest impacts on business performance are related to environmental issues. The environmental dimension assesses the organization's impacts on natural systems, living and nonliving. It covers the performance related to inputs (such as materials, energy, water) and production (emissions, effluents, waste). Also, it considers the performance related to biodiversity, environmental compliance and other relevant information, such as the impacts of products and services. The variable highlighted in this dimension takes into consideration the initiatives to reduce environmental impacts of products and services.

What was also emphasized were the social and economic impacts, with similar averages. In the social dimension, were considered the organization's impacts on the social systems in which it operates. It identifies aspects of business related to labor practices, human rights, society and product responsibility. The variables most prominent in this category relate to health and safety, and training programs for employees.
The economical dimension assesses the organization's impacts on the economic conditions of its stakeholders and on economic systems at the local, national and global level. It illustrates the flow of capital among the different stakeholders and the organization's main economic impacts on society. The variable referring to the increased economic value generated and distributed can be highlighted, which obtained the highest average in this category.

According to these results, one can see a balance between the impacts in the three dimensions analyzed, with greater evidence of environmental issues, which had the highest averages.

In relation to business performance indicators, it is possible to identify economic and environmental performance variables, according to results presented in Table 6 below. 
According to the data presented, higher averages are identified in economic performance indicators, showing positive results. Regarding the variable referring to the reduction of fines and penalties from pollution, an average of $81.82 \%$ was obtained of improvement in the companies surveyed. These results confirm that the efforts in pursuit of sustainable development can promote satisfactory economic benefits.

Therefore, it is possible to identify business performance, in economic, social and environmental terms, through impacts and indicators, in the surveyed companies. It can be noticed, among impacts, that environmental issues stood out, as well as several variables of social and economic impacts that had high averages among the participating companies. Among the performance indicators, economic indicators can be highlighted.

\section{Final Considerations}

This study aimed at identifying the water use management practices and the business performance, in economic, social and environmental terms, in industries of the Brazilian mineral sector. In this sense, the main findings of the study can be highlighted.
Among the practices adopted by the enterprises surveyed regarding the management of water use, stand out those which relate to the evaluation of the risks involved and controls at the operational level in order to decrease the amount of water used and the discharge of wastewater. Despite this, it is clear a need for industries to come closer to their stakeholders and supply chain, in search of a more integrated and participatory management, since these dimensions achieved the lowest results.

The business performance of the industries surveyed was also verified, through impacts and indicators in economic, environmental and social terms. Among the impacts, those related to environmental issues can be highlighted, which obtained the best averages. Among the indicators, the best results were obtained regarding economic performance.

Finally, we highlight the importance of this study for environmental management and, in particular, in what concerns the processes of water use management, especially in sectors impacted by such issues, like mining. In this sense, it is essential to discuss, in the academic and business fields, the aspects related to this subject. Thus, the results of this study provide a reflection on the importance of water use management and business performance in economic, social and environmental terms.

\begin{tabular}{|l|c|c|c|}
\hline \multicolumn{3}{|c|}{ Business performance - Indicators } \\
\hline \multicolumn{1}{|c|}{ Variables } & Mean $^{\mathbf{1}}$ & $\begin{array}{c}\text { Standard } \\
\text { Deviation }\end{array}$ & $\begin{array}{c}\text { Variation } \\
\text { coefficient }\end{array}$ \\
\hline 1 Economic performance ${ }^{2}$ & 50.29 & 29.042 & 0.58 \\
\hline 1.1 Cost saving due to reduced consumption of water and energy & 42.80 & 27.767 & 0.65 \\
\hline 1.2 Cost saving due to the recycling waste & 40.80 & 28.272 & 0.69 \\
\hline 1.3 Cost saving due to decreased effluent & 34.74 & 32.552 & 0.94 \\
\hline 1.4 Reduction of fines and penalties for pollution & 81.82 & 28.391 & 0.35 \\
\hline 2 Socio-Environmental Performance ${ }^{2}$ & 42.32 & 26.789 & 0.63 \\
\hline 2.1 Preservation of local, regional and global natural resources & 70.33 & 25.795 & 0.37 \\
\hline 2.2 Reduction of gas emissions & 48.08 & 34.061 & 0.71 \\
\hline 2.2 Reduction in water consumption & 40.36 & 33.498 & 0.83 \\
\hline 2.3 Reduction in power consumption & 37.42 & 30.328 & 0.81 \\
\hline 2.4 Use of alternative energy sources & 29.44 & 27.754 & 0.94 \\
\hline 2.5 Eco-efficient products among the company's products & 37.22 & 37.070 & 1.00 \\
\hline 2.6 Improving the health, safety and quality of life in society & 48.62 & 35.629 & 0.73 \\
\hline 2.7 Investment in environmental programs considering the turnover in & 36.67 & 37.170 & 1.01 \\
\hline 2010 & 33.97 & 35.742 & 1.05 \\
\hline 2.8 Investment in social programs considering the turnover in 2010 & 36.59 & 38.526 & 1.05 \\
\hline 2.9 Investment in certifications considering turnover in 2010 & & \\
\hline
\end{tabular}

Table 6 - Business performance (indicators) - descriptive statistics

'The means refer to the percentage (from $0 \%$ to $100 \%$ ) of evolution, according to the companies, of the indicators analyzed in 2010. ${ }^{2}$ The means of each dimension were calculated from the arithmetic mean of its variables.

ISSN: 07I 8-2724. (http://www.jotmi.org)

Journal of Technology Management \& Innovation (c) Universidad Alberto Hurtado, Facultad de Economía y Negocios. 


\section{References}

AGÊNCIA NACIONAL DE ÁGUAS (BRAZIL) - ANA; INSTITUTO BRASILEIRO DE MINERAÇÃO - IBRAM (2006). A gestão dos recursos hídricos e a mineração.ANA: Brasília.

AZAPAGIC,A. (2004). Developing a framework for sustainable development indicators for the mining and minerals industry. Journal of Cleaner Production. 12(6): 639-662. doi: 10.1016/S0959-6526(03)00075-I.

BANCO NACIONAL DE DESENVOLVIMENTO ECONÔMICO E SOCIAL - BNDES. (2011). Circular $n^{\circ}$ 34, de 06 de setembro de 201l. http://www.bndes.gov.br/ SiteBNDES/export/sites/default/bndes_pt/Galerias/Arquivos/produtos/download/Circ034_II.pdf [I2 January 20I2]

BARBIERI,J.C. et al.(20I0) Inovação e sustentabilidade:novos modelos e proposições. Revista de Administração de Empresas, 50(2), I 46-I54. doi: I0.1590/s0034-759020I0000200002

BARBIERI, J. C. (2007). Gestão ambiental empresarial: conceitos, modelos e instrumentos. (2nd ed.). Saraiva: São Paulo.

BELLEN, H. M. van (2006). Indicadores de sustentabilidade. (2nd ed.). FGV: Rio de Janeiro.

BRAZIL. (1997). Law n 9.433, 8 January 1997. Diário Oficial [da] República Federativa do Brasil, Poder Executivo: Brasília, CEO WATER MANDATE; THE UNITED NATIONS ENVIRONMENT PROGRAMME - UNEP; THE GLOBAL COMPACT - GC. (2010). Corporate Water Accounting:An Analysis of Methods and Tools for Measuring Water Use and Its Impacts. Pacific Institute.

CERES. (2010). Murky waters? Corporate reporting on water risk: a benchmarking study of 100 companies. http:// www.ceres.org/resources/reports/corporate-reporting-onwater-risk-010/view [23 October 20I I].

DEPARTAMENTO NACIONAL DE PRODUÇÃO MINERAL - DNPM. (2009). Economia mineral do Brasil. Antonio Fernando da Silva Rodrigues (coord.). DNPM: Brasília-DF.

EMBRAPA. (2009). A água nossa de cada dia. http://www. embrapa.br/embrapa/imprensa/artigos/2009/a-agua-nossade-cada-dia [28 June 20II]

GERBENS-LEENES, P.W., Hoekstra, A.Y. (2008). Business water footprint accounting: a tool to assess how production of goods and services impacts on freshwater resources worldwide, Value of Water Research Report Series No.27, UNESCO-IHE, Delft. http://doc.utwente.nl/59999/I/Gerbens08business.pdf [09 January 20I2].
GLOBAL ENVIRONMENTAL MANAGEMENT INITIATIVE - GEMI. (2002). Connecting the drops toward creative water strategies: a water sustainability tool. http://www.gemi.org/ waterplanner/index.htm [09 January 2012].

GLOBAL MINING INITIATIVE - GMI. (20I2). Global Minning Initiative. http://www.globalmining.com/index.asp [06 January 20I2].

GLOBAL REPORTING INITIATIVE - GRI. (2006). Sustainability Reporting Guidelines. http://www.globalreporting.org [09 January 2012].

GLOBAL REPORTING INITIATIVE - GRI. (20I0). Mining and metals sector supplement. http://www.globalreporting. org/ReportingFramework/SectorSupplements/MiningAndMetals [23 October 20II].

GUNSON, A. J., Klein, B.,Veiga, M., Dunbar, S. (20I2). Reducing mine water requirements. Journal of Cleaner Production. 2 I (I): 7I-82. Jan. doi: I0.1016/j.jclepro.20II.08.020

HAIR, JR., J. F. et al. (2003). Essentials of Business Research Methods. Leyh Publishing, LLC.

HILSON, G.; Murck, B. (2000). Sustainable development in the mineral industry: clarifying the corporate perspective. Resources Policy. 26: 227-238. doi: 10.1016/S030I4207(00)0004I-6.

LACY, P. et al. (2010).A new era of sustainability: CEO reflections on progress to date, challenges ahead and the impact of the journey toward a sustainable economy. UN Global Compact - Accenture Sustainability Services.

LAMBOOY, T. (20II). Corporate social responsibility: sustainable water use. Journal of Cleaner Production. 19: 852866. doi: 10.1016/j.jclepro.2010.09.009.

MALHOTRA, K. N.; Birks, D. (2006). Marketing Research:An Applied Approach. FT Prentice Hall.

MCLELLAN, B.C. et al. (2009). Incorporating sustainable development in the design of mineral processing operations - Review and analysis of current approaches. Journal of Cleaner Production. 17: 1414-1425. doi: 10.1016/j. jclepro.2009.06.003

MIRANDA, E. E. de. (2004). A água na natureza e na vida dos homens. Ideias e Letras:Aparecida

SAVITZ, A. W.; Weber, K. (2006). The triple bottom line: how today's best-run companies are achieving economic, social, and environmental success - and how you can too. Jossey-Bass. 
SERVIÇO BRASILEIRO DE APOIO ÀS MICRO E PEQUENAS EMPRESAS - SEBRAE. (2004). Fatores condicionantes e taxa de mortalidade de empresas no Brasil. Research. Brasília. http://www.sebrae.com.br [12 jan. 20I2].

TUNDISI,J.G.(2008). Recursos hídricos no futuro:problemas e soluções. Estudos Avançados, 22(63), 7-16. doi:10.1590/ s0I 03-40I 42008000200002

WBCSD. Global Water Tool. (2007). http://www.wbcsd.org/ work-program/sector-projects/water/global-water-tool. aspx. [09 January 2012].

WORLD COMMISSION ON ENVIRONMENT AND DEVELOPMENT (WCED). (1987). Our Common Future. Oxford University Press: Oxford. 